\title{
ReCOMmendations for the treatment of INFLUENZA in children for Primary care physiciAnS - COMPAS INFLUENZA
}

\author{
Recommendations developed by the following experts: Polish Society of Pediatric Pneumology, \\ Polish Pediatric Society, Polish Society of Vaccinology, Polish Society of Family Medicine
}

\author{
ZBIGNIEW DONIEC ${ }^{1, A, ~ D-F}$, AGNIESZKA MASTALERZ-MIGAS ${ }^{2, A, ~ D-F}$, TERESA JACKOWSKA ${ }^{3, \text { A, D-F, }}$ \\ ERNEST KUCHAR ${ }^{4, A, D-F}$, ADAM SYBILSKI ${ }^{5, A, D-F}$
}

\author{
${ }^{1}$ Department of Pneumonology of the Institute of Tuberculosis and Lung Diseases, Regional Department \\ in Rabka-Zdroj \\ ${ }^{2}$ Department of Family Medicine, Wroclaw Medical University \\ ${ }^{3}$ Department of Paediatrics, Medical Centre for Postgraduate Education in Warsaw \\ ${ }^{4}$ Department of Paediatrics with the Observation Unit of the Medical University of Warsaw \\ ${ }^{5}$ Department of Paediatrics and Neonatal Diseases of the Central Clinical Hospital of the Ministry of Interior \\ and Administration in Warsaw
}

A - Study Design, B - Data Collection, C - Statistical Analysis, D - Data Interpretation, E - Manuscript Preparation, F - Literature Search, G - Funds Collection

Summary Influenza is an acute infectious disease of the airways that occurs in every age group. The course of the disease may have a different severity and clinical picture, from asymptomatic to severe with symptoms of respiratory failure. The possibilities of pandemic infections and serious complications throughout the course of influenza distinguish it from other viral respiratory diseases, prompting us to treat it in a special way. Diagnosis of the disease is usually clinical in nature, and additional studies may be helpful in clinically relevant cases. The drug recommended for treatment and chemoprophylaxis is oseltamivir. Clinical benefits are greatest if treatment starts as early as possible, within 48 hours of the first symptoms of influenza. Clinical studies indicate that early treatment with oseltamivir may shorten the duration of the disease and reduce the risk of its complications. Annual influenza vaccination is the most effective method of preventing this disease, and the only contraindication to vaccination is the occurrence of an anaphylactic or other severe allergic reaction after a previous vaccination.

Key words: influenza, children, treatment, vaccinations.

Doniec Z, Mastalerz-Migas A, Jackowska T, Kuchar E, Sybilski A. ReCOMmendations for the treatment of INFLUENZA in children for Primary care physiciAnS - COMPAS INFLUENZA. Fam Med Prim Care Rev 2019; 21(2): 189-198, doi: https://doi.org/10.5114/ fmpcr.2019.82984.

\section{Background}

Influenza is an acute respiratory disease which occurs in all age groups. The course of the condition may have different severity and clinical picture, from asymptomatic to severe with symptoms of respiratory failure [1, 2]. Influenza is one of the most common acute respiratory diseases of the viral aetiology. In practice, it is not always properly diagnosed due to numerous similarities to the ordinary "common cold", especially at an early stage of the clinical course. The possibilities of pandemic and serious complications distinguish this condition from other viral respiratory diseases $[1,2]$.

The influenza virus belongs to the Orthomyxoviridae family and has significant affinity for the airway epithelium. In humans, infections caused by the type $A$ and $B$ virus are important from the clinical point of view, while type $C$ has less epidemiological significance. Influenza A and B viruses contain genome (single-stranded, segmented, negative-polarity RNA), protein capsid with antigenic proteins on the surface - neuraminidase (NA), haemagglutinin (HA) and lipoprotein capsule [3].

Influenza A virus has many subtypes, with differentiation based on HA antigenic properties ( $\mathrm{H} 1$ to $\mathrm{H} 18$ subtypes) and NA
(N1 to N11 subtypes). In humans, three HA subtypes: H1, H2, $\mathrm{H} 3$, and two NA subtypes: N1 and N2, are common. H3N2 was the subtype of virus $A$ most frequently detected in the years 1994-2005 (90.6\%), and since the outbreak of the pandemic in 2009 - AH1N1 [1]. Influenza A is infectious to humans and many species of animals; the extent of an epidemic/pandemic is unpredictable and depends on the type of interaction between the virus and the host cells, as well as on ecological factors.

Virus B contains only one type of HA and NA belonging to one of two genetic lines: Yamagata or Victoria. In humans, the type B virus causes infections; they usually run in a clinical manner which is indistinguishable from the infections caused by type $A$ viruses [1, 3].

The influenza $A$ virus is characterised by high antigenic variability of HA and NA proteins, which mainly results from relatively frequent RNA mutations and minor errors accumulated during RNA copying (antigenic drift or antigenic shift, otherwise known as reassortment) [4]. These changes are caused by the enzyme responsible for RNA replication (RNA polymerase); new mutations arising from RNA polymerase errors can increase virulence, facilitate adhesion of the virus to the respiratory epithelium and its replication. Because changes in the virus genome are continuous, they allow for the annual spread of the disease 
among people who have not acquired immunity as a consequence of contracting influenza in a given season or as a result of vaccination. The high genetic variability of the influenza A virus leads to the formation of new, sometimes very pathogenic strains. Type $B$ and $C$ viruses have high genetic stability.

\section{Epidemiology}

Influenza is the most dangerous of common viral respiratory infections. In the temperate climate zone, influenza is diagnosed every year in the winter months. The influenza season in the northern hemisphere falls from October to April, reaching its peak usually at the end of February [5]. According to the WHO, on average $20-30 \%$ of children and $5-10 \%$ of adults suffer from full-blown flu [6]. It is most common among children aged 5-14 years, while the risk of severe influenza is the highest in children aged 6 months to 4 years and those chronically ill, especially with neurological disorders which impair ventilation and impede expectoration, as well as in patients with chronic lung diseases, for instance bronchopulmonary dysplasia. The ECDC (European Centre for Disease Prevention and Control) estimates that annually in European Union countries, influenza may affect $10-30 \%$ of the population, with a predominance among children [7]. On the other hand, a meta-analysis conducted in randomised trials shows that in the influenza epidemic season, an average of $10.5 \%$ of school-age children suffer from this disease, along with as much as $32 \%$ of children under 6 years of age compared to about $2.5 \%$ of adults; therefore, children constitute the largest group of the infected and sick [8,9]. Although flu seasons differ significantly from each other due to the random mutation of influenza viruses, variable circulation of the viruses and different effectiveness of vaccines, resulting from the difficulties in the annual adjustment of the vaccine composition, the average pathogenicity of the influenza virus is huge. In Poland, several million suspected influenza (flu-like illness) cases are reported annually, out of which more than ten thousand are admitted to hospital, and the number of deaths is unknown (official reports list several to 100 deaths per year, while in Poland, the ECDC estimates deaths at 6.000). In 2017, a total of 5043491 cases of influenza and suspected flu were registered in Poland (incidence 13 126.5/100 thousand), 17118 hospitalisations $(0.34 \%)$ and 47 deaths. Among children under the age of 14, 2269154 cases of flu and suspected influenza were reported (incidence 39 130.5/100.000), and 9411 children were admitted to hospitals $(0.41 \%)$, whilst no deaths were recorded [10]. The summary of epidemiological data from the years 2013-2018 is presented in Tables $1 \mathrm{a}$ and $1 \mathrm{~b}$.

\section{Reporting the case and a suspicion of influenza}

In the epidemic season, entities providing outpatient health care services are obliged to make reports on the MZ-55 forms (weekly and, in the period of significantly higher incidence, daily). According to the definition adopted for the purpose of infectious diseases surveillance in European Union countries (Journal of Laws L 159 of 18.6.2008, p. 46), the reports should include the cases of flu (diagnosed clinically and/or in laboratory tests) and all clinically diagnosed flu-like illnesses, as well as acute respiratory infections which meet the criteria listed in the form. The MZ-55 forms are available on the websites of local sanitary and epidemiological stations or can be generated directly from a computer program developed for medical entities.

Flu, diagnosed clinically and/or in laboratory tests, also requires notification on the ZLK-1 infectious disease report form in accordance with the Act of $5^{\text {th }}$ December 2008 on the prevention and control of infections and infectious diseases in humans (Journal of Laws of 2018, item 151).

It should be noted that correct reporting of all cases of influenza by all medical entities designated for this purpose (NIZP$-\mathrm{PZH})$ is crucial for the epidemiological data collected by the units to reflect the real situation.

\section{Clinical picture}

Flu is characterised by a sudden onset, with fever, a feeling of cold, chills, headache, muscle and joint pain, general malaise, no appetite and weakness. The general symptoms are accompanied by dry cough and nasal congestion, sometimes with watery exudation. The patient may complain of photophobia and other ocular symptoms, such as conjunctival hyperaemia, tearing and burning eyes, as well as acute retro-bulbar pain (about $20 \%$ of patients), and he/she may have red face, hot and wet skin. Sometimes, there is a sore throat, hoarseness, enlarged cervical lymph nodes (about $25 \%$ ), rarely diarrhoea $(<5 \%)$; however, the general symptoms usually obscure other ailments. Hearing sounds over the lungs are reported in over $20 \%$ of patients. Fever is a constant feature of influenza, usually lasting for 3-5 days, but in approximately $1 / 5$ of patients, fever lasts for 7-10 days or longer. Children run a higher fever than adults, although in infants the temperature does not have to rise as high as in older children and young adults. The temperature usually rises rapidly in the first 12 hours of the disease, i.e. at the time when the general symptoms appear. A fever can provoke seizures, especially in the first 2 years of life. The most nagging initial com-

Table 1a. Influenza epidemiology: a summary of the last 5 influenza epidemiological seasons in Poland (developed by [10])

\begin{tabular}{|l|l|l|l|l|l|}
\hline Season & $2013 / 2014$ & $2014 / 2015$ & $2015 / 2016$ & $2016 / 2017$ & $2017 / 2018$ \\
\hline Cases & 2761523 & 3774798 & 4069654 & 4844024 & 5385962 \\
\hline Hospitalisations & 9374 & 12227 & 16156 & 16970 & 18561 \\
\hline Hospitalisations/cases (\%) & $0.33 \%$ & $0.32 \%$ & $0.39 \%$ & $0.34 \%$ & $0.34 \%$ \\
\hline Deaths & 15 & 11 & 140 & 25 & 47 \\
\hline
\end{tabular}

Table 1b. Deaths depending on the age of the influenza patient (developed in accordance with [10])

\begin{tabular}{|c|c|c|c|c|c|}
\hline Age & $0-4$ years & 5-14 years & $15-64$ years & +65 years & Total \\
\hline \multicolumn{6}{|l|}{ Season } \\
\hline $2013 / 2014$ & 0 & 1 & 6 & 8 & 15 \\
\hline $2014 / 2015$ & 0 & 0 & 9 & 2 & 11 \\
\hline $2015 / 2016$ & 3 & 2 & 79 & 56 & 140 \\
\hline $2016 / 2017$ & 0 & 0 & 5 & 20 & 25 \\
\hline $2017 / 2018$ & 0 & 0 & 20 & 27 & 47 \\
\hline
\end{tabular}


plaints are headaches and muscle pain, the severity of which is usually connected with the height of the fever. Muscle pain can involve the limbs or long muscles of the back. Joint pain, without arthritis, is equally common. Respiratory symptoms, usually a dry cough and watery nasal discharge, are generally present at the onset of the disease, but these aliments are usually obscured by the general symptoms. In young children, high fever with the accompanying neurological symptoms (encephalopathy or febrile convulsions) may be the only symptom of influenza; a significant percentage of children may develop bronchitis. On the second or third day of the disease, fever and other general symptoms begin to subside. In contrast, respiratory symptoms, especially dry cough, become more visible and last usually for 3 to 4 days, though coughing and weakness usually last longer (more than 2 weeks). In some patients, poor well-being and chronic fatigue may persist for several weeks. It should be emphasized that new-borns and infants may also suffer from influenza; the younger the child, the less specific the symptoms may be. The clinical symptoms of influenza caused by type $A$ and $B$ viruses are similar.

\section{Diagnosis}

According to international and national guidelines, clinical symptoms and physical examination are sufficient to make a diagnosis in outpatient settings during the epidemic season (October-April) [11-13]. The knowledge of the current epidemiological situation, regular reporting of patients with flu-like symptoms, reports on increased incidence of flu, as well as information on contact with a person suffering from influenza confirmed in the medical history, are helpful in diagnosing influenza.

Clinical symptoms: general symptoms prevail, sudden onset with a high fever $>39^{\circ} \mathrm{C}$, highest on the first day, features of acute, toxic infection (malaise, significant weakness, chills, headaches and muscle pain), muscle and joint pain, dry cough, less common conjunctivitis, sore throat and wheezing.

Leucopoenia with lymphocytosis in the peripheral blood count is helpful in diagnosing influenza. Positive results of Rapid Influenza Diagnostic Tests (RIDTs), which detect the $A$ and $B$ virus but do not determine the strain, may be helpful in diagnosing influenza. The advantage of the tests is the short waiting time for the result (several minutes) and their high specificity, but relatively low sensitivity (60-70\%), which means that a negative test result does not allow for the exclusion of influenza [14]. The most accurate method is to identify the genetic material of the virus in the material collected from the patient (nose or nasopharynx smear, aspirate from the nasal part of the throat, etc.) by means of RT-PCR (Reverse Transcriptase Polymerase Chain Reaction); however, this should be done no later than on day 7 from the beginning of the symptoms $[15,16]$.

\section{Differentiation}

Influenza-like illness caused by other viruses, including RSV, atypical pneumonia, viral pharyngitis, sepsis, infectious mononucleosis, enterovirus (e.g. Coxsackie), rotavirus and norovirus (colloquially, "intestinal flu").

\section{Complications}

In the majority of children, flu is uncomplicated, with a high fever lasting for 3-4 days, sometimes for 6-8 days. Recovery usually occurs after 1-2 weeks. Even in previously healthy children, the course of influenza can be serious, with organ complications or bacterial superinfections, circulatory insufficiency and sudden death.

The group at higher risk of severe influenza and complications is children:
- $\quad$ within the age of 6-59 months;

- chronically ill with coexisting lung diseases, including asthma, cardiovascular system (with the exception of isolated hypertension), renal, hepatic, neurological, haematological or metabolic disorders, including diabetes;

- with immunodeficiency, including those infected with HIV;

- $\quad$ receiving aspirin for a long time (increased risk of Reye syndrome);

- $\quad$ staying in long-term care centres;

- extremely obese.

The most common complications of influenza in children include: acute otitis media, bronchitis, primary viral pneumonia, secondary bacterial pneumonia, tracheitis, subglottic laryngitis, mild inflammation of the muscles (usually influenza $B$, possible myoglobinuria, occasionally with kidney damage), myocarditis, pericarditis and central nervous system complications: fever convulsions, encephalopathy, transverse myelitis, Guillain-Barré syndrome and Reye syndrome $[17,18]$.

Bacterial pneumonia occurs during the recovery from influenza or in the convalescence phase (another episode of fever, worsening of breathlessness, coughing, weakness after clinical improvement). The most common bacteria responsible for pneumonia are: S. pneumoniae, S. aureus, $H$. influenzae and others. Bacterial superinfections are manifested by deviations in complete blood count: leukocytosis $>15 \times 10^{3} / \mathrm{mm}^{3}$, especially an elevated neutrophil count $10 \times 10^{3}$ and high inflammatory marker rates (CRP and procalcitonin). Less common complications include: toxic shock syndrome, Goodpasture's syndrome, anosmia, ageusia (the loss of smell and taste) and balance disorders [19]. The mortality rate among children with influenza is highest, and complications are most frequent in the first two years of life; the rates are high in small children and those chronically ill - especially with immunity and neurological disorders which impair lung ventilation and hinder expectoration of secretions. Red-flag symptoms indicating possible complications and requiring clinical re-evaluation are presented in Table 2 . These symptoms are an indication for hospitalisation, 24-hour monitoring of the patient's condition, as well as laboratory and imaging tests (chest X-ray, transthoracic ultrasound of the chest).

Table 2. Red-flag clinical symptoms of influenza indicating possible complications

- $\quad$ persistent or recurrent high fever or other symptoms after 3 days

- symptoms of cardio-respiratory failure: dyspnoea, cyanosis, haemoptysis, chest pain, hypotension, decrease in oxygen saturation of haemoglobin

- $\quad$ symptoms indicating CNS complications: consciousness disturbances, loss of consciousness, pathological drowsiness, recurrent or sustained seizures, significant weakness, paralysis or paresis

- $\quad$ signs of severe dehydration: prolonged capillary return, decreased activity, dizziness or fainting while trying to get up or reduced diuresis

- laboratory symptoms of secondary bacterial infection

\section{Symptomatic treatment}

In the majority of healthy people, influenza is a self-limiting, uncomplicated disease [20]. In such cases, symptomatic treatment is sufficient (Figure 1) [21]. The strategies for symptomatic treatment of influenza include $[13,22]$ :

- $\quad$ proper hydration of the patient - the recommendation of abundant oral fluid administration, which is crucial in the course of fever, moisturising of the airways and facilitating the respiration and evacuation of secretions (especially important in children); 


\section{Uncomplicated flu-like illness}

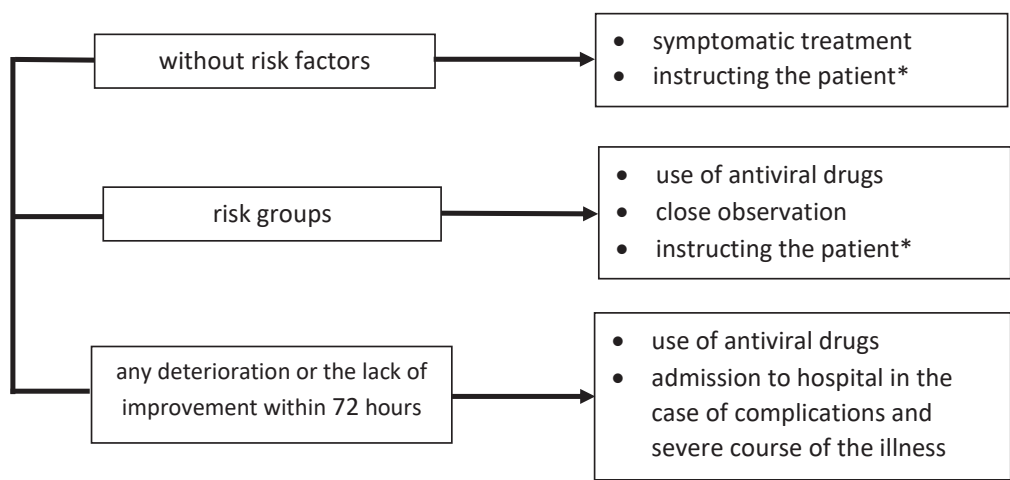

Figure 1. Initial clinical management in uncomplicated flu-like illness or influenza (according to [21])

* When to report to the doctor again (red-flag flu symptoms).
- administration of antipyretic drugs and analgesics (ibuprofen, paracetamol) which reduce chills, muscle pain and tachycardia due to influenza. However, it should be emphasised that there is no clinical data indicating that antipyretic and anti-inflammatory therapy shorten the duration of influenza symptoms. Acetylsalicylic acid is not recommended for children under the age of 18 years due to the possibility of Reye syndrome;

- rest and convalescence at home for up to 24 hours after fever has dissipated. This is of particular importance to minimise the complications of influenza, as well as the transmission and spread of the virus [20];

- $\quad$ antitussive drugs - in severe, tiring, dry cough [23];

- medicines for reducing swelling of the nasal mucosa - decongestants, saline solutions.

There are currently no clinical results of the studies conducted in animals or humans indicating a beneficial effect of natural or herbal therapy in flu. There are no indications and no herbal, natural or other non-prescription (OTC) preparations recommended for the symptomatic treatment of influenza in adults and children [24].

\section{Causative treatment - antiviral drugs}

In causative/antiviral treatment of influenza, we use preparations of neuraminidase inhibitors [13, 25-28]. The neuraminidase inhibitors registered in Poland are as follows:

- $\quad$ oseltamivir - oral medicine;

- zanamivir - a drug for inhalation (a medicine not available in Poland, possible to be brought in as part of a target import during an epidemic of influenza).

Currently, due to the high level of resistance of AH3N2 and AH1N1 type viruses to amantadine, it is not recommended for the treatment of influenza $[13,28]$.

Inhibitors of neuraminidase, which is an enzyme necessary for replicated virions to leave the host cell, effectively inhibit the spread of the virus in the body and prevent the symptoms of influenza [28]. Oseltamivir is effective against influenza A and B viruses. It is estimated that the resistance of the currently occurring strains of influenza $A$ to the drug is below $1 \%$. Type $B$ of the virus is $100 \%$ sensitive $[29,30]$.

The clinical efficacy of oseltamivir has been confirmed in many studies. The use of a neuraminidase inhibitor reduces the severity of influenza symptoms, shortens the duration of fever and other symptoms, as well as reduces the risk of complications (including the need for taking antibiotics) and hospitalisation [20,31-33]. Antiviral drugs shortened the duration of outpatient care and hospital stay in patients with influenza, as well as diminished the risk of death [34].

The American Academy of Paediatrics (AAP) recommends using neuraminidase inhibitors for the treatment and chemoprophylaxis of influenza in children, as they are the best studied antiviral drugs at present. Indications for their use are included in Table 3 [35]. Antiviral treatment (oseltamivir) is also recommended for all people at risk for influenza complications who are suspected of the disease (even in the case of a mild course) as well as for household members of people at risk for influenza complications. According to the recommendations of the Advisory Committee on Immunization Practices (ACIP) from 2018/2019, these include children $<5$ years, especially $<2$ years, all people over 50 , patients with chronic respiratory diseases and those with cardiovascular, metabolic and neurological disorders (Table 4) [35, 36]. At the same time, it should be emphasised that every patient with the symptoms of confirmed flu (especially with severe symptoms) can be treated with antiviral treatment in order to significantly reduce the spread of the virus in the population, especially during an epidemic period.

Table 3. Indications for antiviral treatment in children (modified by authors [35])

Give the medicine to the child (as soon as possible)

Hospitalised with probable influenza

Hospitalised due to severe, complicated or progressive illness associated with influenza, regardless of the duration of symptoms

With suspected flu (with any severity of symptoms) and a high risk of complications

Consider giving the drug

Any healthy child with suspected flu

A child with suspected influenza who stays with children aged $<6$ months or a person with a disease predisposing to complications

Table 4. People from the general population with a higher risk of post-influenza complications and recommendation for antiviral therapy (modified by authors according to $[35,36]$

Recommendation of antiviral treatment in the case of a suspicion or confirmation of influenza infection

Children $<5$ years of age, especially $<2$ years

Persons $\geq 50$ years of age

People with chronic diseases of the following systems:

- respiratory (including asthma),

- cardiovascular (excluding isolated hypertension),

- kidneys, liver,

- haematological (including sickle-cell disease),

- metabolic (including diabetes),

- neurological (including disorders of the CNS, spinal cord, peripheral nerves, muscles, epilepsy, stroke, mental retardation, moderate and severe developmental delays, brain and spinal cord trauma),

- $\quad$ people in immunosuppression (including due to treatment or HIV infection)

All pregnant women or those in the postpartum period during the flu season

Extremely obese people $\mathrm{BMI}>40$

Persons $<19$ years treated for a long time with acetylsalicylic acid

People staying in nursing homes 


\begin{tabular}{|c|c|c|c|}
\hline Trade name & Pharmaceutical form & Registration (treatment, prevention) & Responsible entity \\
\hline Tamiflu* & $\begin{array}{l}\text { capsules, hard, } 30 \mathrm{mg}, 45 \mathrm{mg} \text {, } \\
75 \mathrm{mg} \text { (10 in a package) }\end{array}$ & $\begin{array}{l}\text { for the treatment of adults and children, including new- } \\
\text {-borns born at term; } \\
\text { in infants below } 1 \text { year of age to prevent influenza after } \\
\text { exposure during a pandemic }\end{array}$ & Roche \\
\hline Ebilfumin* & $\begin{array}{l}\text { capsules, hard, } 30 \mathrm{mg}, 45 \mathrm{mg} \text {, } \\
75 \mathrm{mg} \text { (10 in a package) }\end{array}$ & $\begin{array}{l}\text { for the treatment of adults and children, including new- } \\
\text {-borns born at term; } \\
\text { prevention after exposure in people aged } 1 \text { year or older; } \\
\text { in infants below } 1 \text { year of age for the prevention of influenza } \\
\text { after exposure during a pandemic }\end{array}$ & TEVA Pharmaceuticals \\
\hline Tamivil & $\begin{array}{l}75 \mathrm{mg} \text { tablets } \\
\text { (10 in a package) }\end{array}$ & $\begin{array}{l}\text { in adults and children over } 6 \text { years of age or weighing more } \\
\text { than } 40 \mathrm{~kg}\end{array}$ & Biofarm \\
\hline
\end{tabular}

* Instructions for the preparation of suspension are included in the patient leaflet.

Currently, two preparations of oseltamivir, i.e. Tamiflu and Ebilfumin, are registered in Poland. They can be used in treatment from the first days of life. Tamivil can be applied in children over 6 years old, weighing more than $40 \mathrm{~kg}$ (Table 5) [25-27]. It should be emphasised that these drugs are not a substitute for the influenza vaccination [35].

In standard therapy, the drug is given twice a day, in equal 12-hour intervals, for 5 days. In children, the dose depends on age and body weight (Table 6). There is no sufficient data on dosage in premature babies, i.e. born before the $36^{\text {th }}$ week of pregnancy. These children may require a different dose due to physiological immaturity [25]. The treatment should last 5 days. It must not be discontinued, even if the symptoms of influenza are resolved.

\begin{tabular}{|c|c|c|}
\hline & $\begin{array}{l}\text { Treatment } \\
\text { (5 days) }\end{array}$ & $\begin{array}{l}\text { Prophylaxis } \\
\text { (10 days) }\end{array}$ \\
\hline Adults & 75 mg 2 times daily & $75 \mathrm{mg} 1 \mathrm{x}$ day \\
\hline \multicolumn{3}{|l|}{$\begin{array}{l}\text { Children } \\
>12 \text { months* }\end{array}$} \\
\hline$\leq 15 \mathrm{~kg}$ body mass & $30 \mathrm{mg} 2$ times daily & $30 \mathrm{mg} 1 \mathrm{x}$ day \\
\hline $\begin{array}{l}>15-23 \mathrm{~kg} \text { body } \\
\text { mass }\end{array}$ & $45 \mathrm{mg} 2$ times daily & $45 \mathrm{mg} 1 \mathrm{x}$ day \\
\hline $\begin{array}{l}>23-40 \mathrm{~kg} \text { body } \\
\text { mass }\end{array}$ & $60 \mathrm{mg} 2$ times daily & $60 \mathrm{mg} 1 \mathrm{x}$ day \\
\hline$>40 \mathrm{~kg}$ body mass & 75 mg 2 times daily & $75 \mathrm{mg} 1 \mathrm{x}$ day \\
\hline $\begin{array}{l}\text { Infants 0-12 } \\
\text { months }\end{array}$ & $\begin{array}{l}3 \mathrm{mg} / \mathrm{kg} \text { body mass } \\
\text { per dose } \\
2 \text { times daily }\end{array}$ & $\begin{array}{l}3 \mathrm{mg} / \mathrm{kg} \text { body mass } \\
\text { per dose } 1 \mathrm{x} \text { day** }\end{array}$ \\
\hline
\end{tabular}

* In children, the drug should be administered in the form of a syrup. In Poland, the syrup is unavailable, but it is possible for the pharmacist to prepare a suspension from capsules. If preparation in a pharmacy is not possible, the patient can prepare a drug suspension from capsules on his/her own. For infants below the age of 1 year, it is recommended that the product be prepared in a pharmacy, not at home. The preparation instructions are included in the patient leaflet.

** Prophylaxis is not recommended in children $<3$ months, except for life-threatening situations. There is not enough data available in this regard.

Oseltamivir should be administered within 48 hours of the onset of symptoms, preferably as soon as possible. There is no need to obtain a result confirming the presence of the influenza virus infection. In exceptional situations (confirmed severe flu, late reporting of the patient to a doctor, patient at risk of complications), the drug can be used in the subsequent hours and days of the disease, although the therapeutic effect may be weaker [35].
Oseltamivir is administered orally, regardless of meals, although administration with food may improve the gastrointestinal tolerance of the drug. In children, the drug should be administered in the form of a syrup. The suspension may be prepared from capsules by a pharmacist in a pharmacy (the preferred way) or, in the absence of such an opportunity, by parents at home. For infants under 1 year of age, it is recommended that the product be prepared in a pharmacy, not at home. The patient leaflet contains detailed instructions on how to prepare the fluid from capsules [26].

Oseltamivir is safe and has a small number of side effects. These usually included single episodes of symptoms which appeared on the first or second day of treatment and resolved spontaneously within 1-2 days [36]. The most common adverse reactions were gastrointestinal symptoms, such as nausea and vomiting (Table 7) $[25,26,37]$. The pharmacokinetic mechanisms of oseltamivir, including low protein binding and the metabolism which is independent of CYP450 systems and glucuronidase, are unlikely to cause clinically significant drug interactions [37].

\begin{tabular}{|c|c|c|}
\hline & Side effects & Contraindications \\
\hline Tamiflu & $\begin{array}{l}\text { - nausea, vomiting and } \\
\text { diarrhoea, } \\
\text { - abdominal pain, } \\
\text { - headaches, dizziness, } \\
\text { - insomnia }\end{array}$ & $\begin{array}{l}\text { - hypersensitivity to } \\
\text { oseltamivir phosphate } \\
\text { or any other compo- } \\
\text { nent of the drug }\end{array}$ \\
\hline Ebiflumin & $\begin{array}{l}\text { - nausea and vomiting, } \\
\text { - headaches, dizziness, } \\
\text { - insomnia, } \\
\text { - rare: arrhythmias, } \\
\text { disturbances in } \\
\text { consciousness, convul- } \\
\text { sions }\end{array}$ & $\begin{array}{l}\text { - hypersensitivity to the } \\
\text { active substance or } \\
\text { any of the excipients }\end{array}$ \\
\hline Tamivil & $\begin{array}{l}\text { - headaches, dizziness, } \\
\text { - abdominal pain, } \\
\text { - nausea and vomiting, } \\
\text { - insomnia, } \\
\text { - rare: arrhythmias, } \\
\text { disturbances in } \\
\text { consciousness, convul- } \\
\text { sions }\end{array}$ & $\begin{array}{l}\text { - hypersensitivity to the } \\
\text { active substance or } \\
\text { any of the excipients }\end{array}$ \\
\hline
\end{tabular}

There is no data on the safety and efficacy of oseltamivir administered in children with renal failure (aged 12 years and younger). In adolescents (from 13 to 17 years of age) and adults (especially those over 65 years of age) with renal insufficiency, the dose should be adjusted based on creatinine clearance. For the treatment of patients with creatinine clearance from 10 to $30 \mathrm{ml}$ per minute, we provide a dose of $75 \mathrm{mg}$ once a day for 5 days. For the prevention of influenza in patients with creatinine 


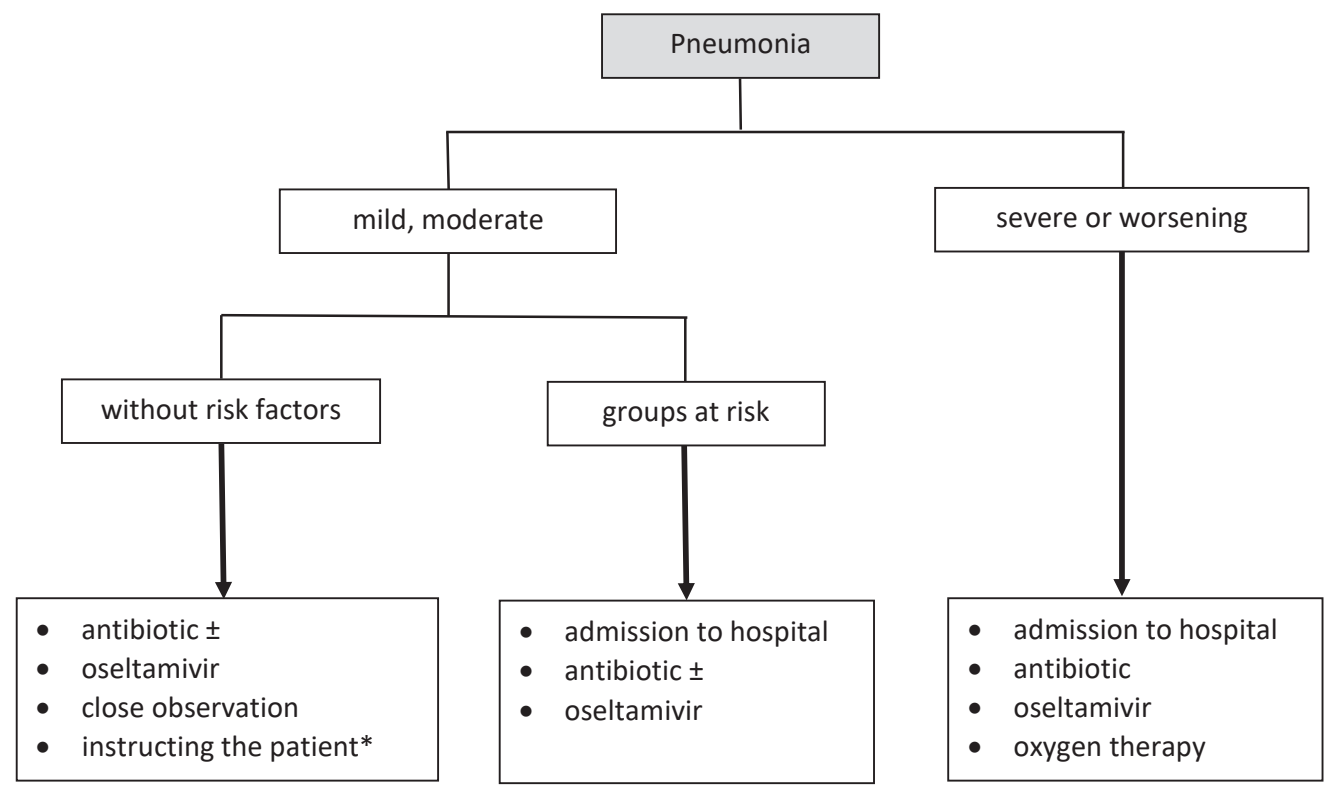

Figure 2. Initial clinical management of pneumonia in the course of influenza depending on the indications and clinical situation (modified by authors [21])

* When the patient should report to the doctor again (red-flag flu symptoms).

clearance from 10 to $30 \mathrm{ml}$ per minute: $30 \mathrm{mg}$ once daily for 10 days after exposure or $75 \mathrm{mg}$ once every other day for 10 days after exposure ( 5 doses). In patients with hepatic insufficiency, it is not necessary to reduce the therapeutic or prophylactic dose $[35,38,39]$.

The medicine should be used to treat and prevent the disease only if reliable epidemiological data indicates that the virus is circulating in the environment and the symptoms suggest the presence of flu infection. Protection against influenza lasts only as long as oseltamivir is administered. It should be emphasised that chemoprophylaxis with the drug is not a substitute for vaccination, which is the most effective form of flu prevention.

Hospitalisation ought to be considered in the case of a severe or worsening course of the disease. In patients at risk, symptoms of pneumonia are an indication for hospitalisation (Figure 2) [21]. The indications for considering hospitalisation in a patient with influenza are presented in Table 8. A patient with respiratory failure should be transferred to a centre performing extracorporeal transmembrane oxygenation (ECMO).

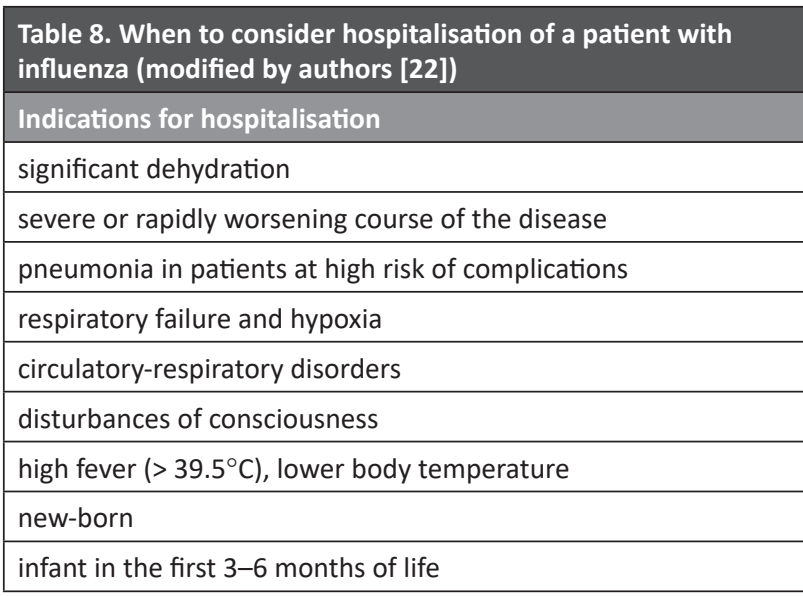

\section{Prophylactic use of antiviral drugs}

Vaccination against influenza, optimally before, but also during the flu season, should be recommended for any child who has no contraindications. The prophylactic use of oseltami- $\operatorname{vir}$ (chemoprophylaxis) may be recommended in order to inhibit the spread of the virus and the development of the disease in people after contact with patients suffering from influenza [21].

Post-exposure prophylaxis is recommended for unvaccinated children (after contact with a patient with clinically diagnosed influenza) [20]:

- $\quad$ with a high risk of influenza complications;

- with close contact with sick people (living in the same flat);

- $\quad$ persons caring for children under 6 years of age, as these children can not be vaccinated.

In exceptional situations, pre-exposure prophylaxis may be used. This is recommended in children at high risk of complications (e.g. undergoing immunosuppression), when protection against influenza is impossible [13].

In addition, CDCs (Centers for Disease Control and Prevention) recommend the use of chemoprophylaxis during the season of the illness in the following cases [40]:

- in children at high risk of influenza complications within 2 weeks after vaccination, when the optimal level of immunity is not yet reached;

- in unvaccinated family members or health care and care facility workers (nurseries, kindergartens) who are in permanent or close contact with unvaccinated children at high risk of influenza complications or unvaccinated infants and young children up to 24 months of age;

- as a complement to vaccination in children at high risk of influenza complications, including immunocompromised individuals who may not develop a sufficient immune response to the vaccine.

Chemoprophylaxis is not routinely recommended for children under 3 months of age due to the lack of data on efficacy and safety at this age group.

\section{Influenza prevention - vaccinations}

Vaccinations are the most effective form of flu prevention and protection against a severe course of the disease and its complications $[1,41]$. During the flu season, higher incidence rates of epidemic influenza are usually reported in children than in the rest of the population; moreover, the increased morbidity is accompanied by more severe or fatal complications. Children 
spend a lot of time in care facilities (nurseries, kindergartens) and schools, where there is a greater risk of mutual infection with influenza. In this group, children under the age of 2 are at higher risk of hospitalisation and complications [35]. The effectiveness of vaccination depends on the appropriate adjustment of the vaccine composition to the strains circulating in the population in a given season of the illness.

According to the Protective Vaccination Program for 2019, flu vaccines are recommended for all healthy children from the age of 6 months to the age of 18 years (with special emphasis on children from the age of 6 to the end of the $60^{\text {th }}$ month) [42]. Similar recommendations are made by the AAP, with special emphasis on children with chronic diseases, which increase the risk of influenza complications [35]. These conditions include:

- asthma and other chronic lung diseases, including cystic fibrosis;

- haemodynamically significant heart disease;

- immunosuppression;

- HIV infection;

- hemoglobinopathies (e.g. sickle cell anaemia);

- $\quad$ illnesses requiring the long-term use of aspirin or medicines containing salicylates, such as juvenile idiopathic arthritis or Kawasaki syndrome, which increase the risk of Reye syndrome in the case of influenza infection;

- $\quad$ kidney and liver disorders (including chronic renal failure);

- metabolic diseases, including diabetes;

- all conditions impairing respiratory functions and increasing the risk of aspiration, such as neurological and neurodevelopmental disorders, spinal cord injuries, paroxysmal disorders and neuromuscular abnormalities.

The AAP emphasises that in order to prevent transmission of the infection to children at risk of influenza complications, vaccination should be provided to the following individuals (unless there are contraindications):

- family members of children at risk and children younger than 5 years of age (in particular, babies younger than 6 months of age), as well as people taking care of these children outside home;

- people in close contact, if they are in a state of immunosuppression;

- pregnant women, those planning pregnancy and in the postpartum period or breastfeeding during the influenza season;

- health care workers;

- $\quad$ people employed in childcare facilities (nurseries, kindergartens, schools, sanatoria, etc.).

The recommendations of the American Advisory Committee on Immunization Practices (ACIP) also indicate the need to reduce the risk of exposing children to influenza complications by vaccinating individuals from their immediate environment who themselves belong to risk groups (Table 4) [36]. In order to reduce influenza virus transmission, it is important to observe the rules of hand and airway hygiene (cough) among children who attend kindergarten and school. Similar rules should be applied in the child's home environment.

Studies also show that vaccination of pregnant women reduces the risk of hospitalisation and influenza complications. Research conducted in the years 2010-2016 demonstrated that the application of vaccines reduced the number of hospitalisations; the effect was estimated at $40 \%$ (95\% Cl: 12-59\%) [43]. In addition, maternal vaccination provides protection for babies in the first 6 months of life, as they receive antibodies passing through the placenta whilst they are too small to receive a vaccine [44-46]. Pregnant women can become vaccinated at any time; vaccination is also safe when breastfeeding, both for mothers and babies. Vaccination given in the third trimester of pregnancy increases the concentration of influenza virus antigen-specific IgA in breast milk; moreover, breastfeeding activates innate antiviral mechanisms, in particular the production of type I interferon [35]. Women who have not received vaccination during pregnancy should also be encouraged to be vaccinated after childbirth, as soon as possible.

Since the 2017/2018 season, the intramuscular Quadrivalent Influenza Inactivated Vaccine (QIIV) has been available in Poland. It contains antigens of two types of influenza viruses $A$ and $B[42,47,48]$. Inactivated influenza vaccines do not contain viruses capable of causing disease, have a well-documented high safety profile, and their use does not pose any significant health risks [35].

One dose of the vaccine should provide protection against influenza within 2 weeks after vaccination. This protection lasts for one season. We give one dose of the vaccine to children over the age of 8 . In children from the age of 6 months up to the age of 8 , who are vaccinated for the first time, we give two doses of the vaccine separated by at least 4-week intervals in order to obtain optimal protection against the infection. It is possible to co-administer the flu inoculation with other vaccines (administered to another location), in accordance with the general principles of vaccine co-administration. In the event of a medical history of febrile seizures, the separate administration of vaccines and/or the prophylactic administration of antipyretics may be considered $[13,48]$. The AAP points out that centres which vaccinate both children and adults should take advantage of the opportunity, and when vaccinating children, encourage adults from their environment (home and outside home) to be vaccinated. This can be done by entering the information about the possibility of adult vaccinations in the child's medical records.

\section{Contraindications and precautions}

Rhinitis, cough and other symptoms of the common cold after vaccination may result from accidental coincidence with the infection caused by completely different viruses or bacteria which often occur in the same season of higher disease incidence (i.e. in autumn and winter). A significant reduction in the risk of potential adverse post-vaccination reactions is influenced by a proper qualification for vaccination, including taking medical history, the performance of a physical examination and determination of temporary and permanent contraindications for vaccinations.

Local reactions, such as pain at the site of injection (in 65\% of people vaccinated), self-limiting redness and oedema lasting 1-2 days after vaccination, are the most common changes after influenza vaccination [13].

General reactions (usually fever, weakness and muscle pain) are equally common after the intramuscular administration of influenza vaccines and after the administration of a placebo; they are more frequent in children vaccinated for the first time in life [1].

Mild symptoms of upper respiratory tract infection or allergic rhinitis, with or without fever, are not contraindications to the use of influenza vaccines. Feverish children with a moderate or severe course of the disease should not be vaccinated until the symptoms subside.

Children vaccinated against influenza did not have a higher risk of Guillain-Barré syndrome (GBS). However, children with a past history of GBS symptoms within 6 weeks of the influenza vaccination not at high risk for a severe course of influenza and/ /or its complications are not advised to be vaccinated [35].

Like all vaccines, certain components of the preparation (e.g. chicken egg protein) may cause allergic reactions of varying severity (pruritus, urticaria, angioedema, anaphylactic reaction) $[1,13,40]$

The qualification for vaccination by a doctor, including the assessment of allergic reactions after previous vaccinations, is an important element of minimising the risk of an allergic post-vaccination reaction. The reaction may be local (erythema, 
oedema and pain) or general (urticaria). An anaphylactic reaction, which is very rare (estimated at approximately 1 case per 1 million of the vaccine doses administered), is the most severe allergic reaction after the administration of the vaccine. An anaphylactic reaction or other serious allergic reactions to any component of the vaccine are the only medical contraindications for influenza vaccination [35].

Children who have previously developed an allergic reaction to any component of the influenza vaccine should be evaluated by an allergist in order to determine if a further dose of the vaccine is appropriate. If there was no anaphylactic reaction after the previous vaccination, the procedure may be performed in accordance with the general recommendations, however, with the need to exercise particular caution and maintain the required observation time after the procedure.

Studies show that people with an allergy to chicken egg protein can safely receive the influenza vaccine exercising standard precautions; an allergy to eggs, regardless of its severity, is not a contraindication to vaccination [49-51]. The AAP recommendations of 2017 stated that [52]:

- all children with an allergy to chicken egg protein of any severity may receive the influenza vaccine without any additional precautions, except for the rules applied for all vaccines;

- the flu vaccine is well-tolerated by people with a history of an allergy to chicken egg protein, regardless of the severity of the allergic reaction observed in the child;

- $\quad$ special precautions for patients with an allergy to chicken egg protein are not justified, as the incidence of an anaphylactic reaction after vaccinating people with this allergy against influenza is not higher than in individuals not suffering from the allergy, nor the incidence reported after receiving other commonly recommended vaccines.

The AAP recommendations of 2018 also emphasise that people with an allergy to chicken egg protein vaccinated against influenza are not more susceptible to systemic allergic reactions than individuals without an allergy to eggs. Precautions, such as the choice of a particular vaccine, special periods of observa-

Source of financing: the work was not financed from external sources. Conflicts of interest: The authors declare no conflicts of interest. tion or limitation of the administration to specific medical conditions, are not justified and constitute an unnecessary barrier to immunisation [35]. A similar stand is taken by the ACIP [53]. In justified situations (e.g. a patient at risk for severe influenza complications), the vaccination can be carried out in a hospital setting [53]. Detailed indications and contraindications for the vaccines used in Poland can be found in the Summary of Product Characteristics (SmPC) [25-27, 54, 55].

In the case of permanent contraindications for influenza vaccination (anaphylaxis with the previous vaccination), the patient should be advised on the possibility of vaccinating the closest environment (family, carers) in order to reduce the risk of transmission of the infection (cocoon strategy). If contraindications are temporary, the patient should be informed about the earliest possible date of vaccination [35]

\section{Summary}

1. Influenza is an acute viral disease with high infectivity and seasonal variability of incidence rates - from local epidemics to general pandemics.

2. The diagnosis of influenza is usually clinical. It may be helpful to perform a quick test in order to detect the virus, but a negative result does not exclude flu.

3. Oseltamivir is the recommended drug for the treatment and prevention of influenza. Clinical benefits are the greatest if the treatment starts as early as possible, within 48 hours of the first symptoms. Clinical studies indicate that early treatment with oseltamivir may shorten the duration of the disease and reduce the risk of complications.

4. Annual vaccination against influenza of children over 6 months and adults is the most effective method of prevention.

5. Vaccination against influenza is most effective before an epidemic season - usually by the end of October, but it is also justified to be given during the whole season of the illness.

6. Influenza vaccination should involve medical personnel and carers of patients at risk.

\section{References}

1. Antczak A. Grypa. Praktyczne kompendium. Warszawa: Medical Tribune Polska; 2015 (in Polish).

2. Mastalerz-Migas A. Grypa, od rozpoznania do leczenia. Praktyczny przewodnik dla lekarzy podstawowej opieki zdrowotnej. Poznań: Biofarm; 2018 (in Polish).

3. Long JS, Mistry B, Haslam SM, et al. Host and viral determinants of influenza A virus species specificity. Nat Rev Microbiol 2019; 17(2): 67-81, doi: 10.1038/s41579-018-0115-z.

4. Kim H, Webster RG, Webby RJ. Influenza Virus: dealing with a drifting and shifting pathogen. Viral Immunol 2018; 31(2): 174-183.

5. Antczak A, Jahnz-Różyk K, Krzywański J, et al. Rekomendacje ekspertów Ogólnopolskiego Programu Zwalczania Grypy dotyczqce profilaktyki grypy w sezonie epidemicznym 2017/2018. Warszawa: FluForum; 2017 (in Polish).

6. World Health Organization. Influenza [cited 21.12.2018]. Available from URL: https://www.who.int/influenza/gisrs_laboratory/flunet/ en/.

7. ECDC. Seasonal Influenza. Factsheet for health professionals 2017 [cited 21.12.2018]. Available from URL: https://ecdc.europa.eu/en/ seasonal-influenza.

8. Demicheli V, Jefferson T, Al Ansary LA, et al. Vaccines for prevention influenza in healthy adults. Cochrane Database Syst Rev 2014; 3 : CD001269, doi: 10.1002/14651858.CD001269.pub5.

9. Hefferson T, Rivetti A, Harnden A, et al. Vaccines for preventing influenza in healthy children. Cochrane Database Syst Rev 2008; 1: CD004879.

10. Krajowy Ośrodek ds. Grypy - Meldunki Epidemiologiczne PZH [cited 21.12.2018]. Available from URL: https://www.pzh.gov.pl/ (in Polish).

11. World Health Organization. Influenza [cited 18.12.2018]. Available from URL: https://www.who.int/influenza/en/.

12. Center for Diseases Control and Prevention [cited 18.12.2018]. Available from URL:https://www.cdc.gov/flu/index.htm.

13. Makowiec-Dyrda M, Tomasik T, Windak A, et al. Profilaktyka i leczenie grypy. Wytyczne Kolegium Lekarzy Rodzinnych w Polsce, 2016. [cited 21.12.2018]. Available from URL: https://klrwp.pl/strona/225/wytyczne-grypa-2016/pl (in Polish).

14. Chartrand C, Leeflang MM, Minion J, et al. Accuracy of rapid influenza diagnostic tests: a meta-analysis. Ann Intern Med 2012; 156(7): 500-511.

15. Wang R, Taubenberger JK. Methods for molecular surveillance of influenza. Expert Rev Anti Infect Ther 2010; 8(5): 517-527. 
16. Brydak LB, Wozniak-Kosek A, Nitsch-Osuch A. Influenza diagnosis and vaccination in Poland. Respir Physiol Neurobiol 2013; 187(1): 88-93.

17. Rosa-Olivares J, Porro A, Rodriguez-Varela M, et al. Otitis media: to treat, to refer, to do nothing: a review for the practitioner. Pediatr Rev 2015; 36(11): 480-486.

18. Kondrich J, Rosenthal M. Influenza in children. Curr Opin Pediatr 2017; 29(3): 297-302.

19. Dawood FS, Chaves SS, Pérez A, et al. Complications and associated bacterial coinfections among children hospitalized with seasonal or pandemic influenza, United States, 2003-2010. J Infect Dis 2014; 209(5): 686-694, doi: 10.1093/infdis/jit473.

20. Ghebrehewet S, MacPherson P, Ho A. Influenza. BMJ 2016; 7: 355, doi: https://doi.org/10.1136/bmj.i6258.

21. World Health Organization. Clinical management of human infection with pandemic influenza (H1N1) 2009: revised guidance. November 2009. Available from URL: www.who.int/csr/resources/publications.

22. Uyeki TM. Influenza. Ann Intern Med 2017; 167(5): 33-48.

23. Doniec Z, Mastalerz-Migas A, Krenke K, i wsp. Rekomendacje postępowania diagnostyczno-terapeutycznego w kaszlu dzieci dla lekarzy POZ. Lekarz POZ 2016; 4: 305-321 (in Polish).

24. Mousa HA. Prevention and treatment of influenza, influenza-like illness, and common cold by herbal, complementary, and natural therapies. J Evid Based Complementary Altern Med 2017; 22(1): 166-174.

25. Tamiflu - charakterystyka produktu leczniczego na dzień 31.08.2018. Available from URL: https://www.ema.europa.eu/documents/ product-information/tamiflu-epar-product-information_pl.pdf (in Polish).

26. Ebilfumin - charakterystyka produktu leczniczego na dzień 27.06.2018. Available from URL: https://www.ema.europa.eu/documents/ product-information/ebilfumin-epar-product-information_en.pdf (in Polish).

27. Tamivil - charakterystyka produktu leczniczego na dzień 19.11.2018. Available from URL: http://www.chpl.com.pl/\#detail=39462504 !87951071 (in Polish).

28. Malosh RE, Martin ET, Heikkinen T, et al. Efficacy and safety of oseltamivir in children: systematic review and individual patient data meta-analysis of randomized controlled trials. Clin Infect Dis 2018; 66(10): 1492-1500.

29. Davlin SL, Blanton L, Kniss K, et al. Influenza activity - United States, 2015-16 season and composition of the 2016-17 influenza vaccine. MMWR Morb Mortal Wkly Rep 2016; 65: 567-575.

30. Garten R, Blanton L, Elal AIA, et al. Update: influenza activity in the United States during the 2017-18 season and composition of the 2018-19 influenza vaccine. MMWR Morb Mortal Wkly Rep 2018; 67(22): 634-642.

31. Dobson J, Whitley RJ, Pocock S, et al. Oseltamivir treatment for influenza in adults: a meta-analysis of randomised controlled trials. Lancet 2015; 385(9979): 1729-1737.

32. Fry AM, Goswami D, Nahar K, et al. Efficacy of oseltamivir treatment started within 5 days of symptom onset to reduce influenza illness duration and virus shedding in an urban setting in Bangladesh: a randomised placebo-controlled trial. Lancet Infect Dis 2014; 14(2): 109-118.

33. Venkatesan S, Myles PR, Leonardi-Bee J, et al. Impact of outpatient neuraminidase inhibitor treatment in patients infected with influenza A(H1N1) pdm09 at high risk of hospitalization: an individual participant data metaanalysis. Clin Infect Dis 2017; 64: $1328-1334$.

34. McGeer A, Green KA, Plevneshi A, et al. Antiviral therapy and outcomes of influenza requiring hospitalization in Ontario, Canada. Clin Infect Dis 2007; 45(12): 1568-1575.

35. AAP Committee on Infectious Diseases. Recommendations for prevention and control of influenza in children, 2018-2019. Pediatrics 2018; 142(4): e20182367.

36. Grohskopf LA, Sokolow LZ, Broder KR, et al. Prevention and control of seasonal influenza with vaccines: Recommendations of the Advisory Committee on Immunization Practices-United States, 2018-19 Influenza Season. MMWR Recomm Rep 2018; 67(3): 1-20, doi: 10.15585/mmwr.rr6703a1.

37. Doll MK, Winters N, Boikos C, et al. Safety and effectiveness of neuraminidase inhibitors for influenza treatment, prophylaxis, and outbreak control: a systematic review of systematic reviews and/or metaanalyses. J Antimicrob Chemother 2017; 72(11): 2990-3007.

38. Uyeki TM. Oseltamivir treatment of influenza in children. Clin Infect Dis 2018; 66(10): 1501-1503.

39. Talbot HK. Influenza in older adults. Infect Dis Clin North Am 2017; 31(4): 757-766.

40. Center Diseases Control and Prevention [cited 25.01.2019]. Available from URL: https://www.cdc.gov/flu/professionals/antivirals/ summary-clinicians.html.

41. Blank P, Falup-Pecurariu O, Kassianos G, i wsp. Szczepienia przeciw grypie: podstawowe fakty dla lekarzy pierwszego kontaktu w Europie (RAISE). Warszawa: Fundacja Nadzieja dla Zdrowia; 2016 (in Polish).

42. Dziennik Urzędowy Ministra Zdrowia [cited 25.01.2019]. Available from URL: https://gis.gov.pl/wp-content/uploads/2018/01/akt.pdf (in Polish).

43. Thompson MG, Jeffrey CK, Regan AK, et al. Influenza vaccine effectiveness in preventing influenza associated hospitalizations during pregnancy: a multicountry retrospective test negative design study, 2010-2016. Clin Infect Dis 2018, doi: 10.1093/cid/ciy737 [Epub ahead of print].

44. Zaman K, Roy E, Arifeen SE, et al. Effectiveness of maternal influenza immunization in mothers and infants. N Engl J Med 2008; 359: 1555-1564.

45. Steinhoff MC, Katz J, Englund JA, et al. Year-round influenza immunisation during pregnancy in Nepal: a phase 4, randomised, placebocontrolled trial. Lancet Infect Dis 2017; 17(9): 981-989.

46. Madhi SA, Cutland CL, Kuwanda L, et al. Maternal Flu Trial (Matflu) Team. Influenza vaccination of pregnant women and protection of their infants. N Engl J Med 2014; 371: 918-931.

47. Tisa V, Barberis I, Faccio V, et al. Quadrivalent influenza vaccine: a new opportunity to reduce the influenza burden. $J$ Prev Med Hyg 2016; 57(1): E28-E33.

48. Centers for Disease Control and Prevention. Prevention and control of influenza with vaccines: recommendations of the Advisory Committee on Immunization Practices, United States, 2018-19 influenza season. MMWR Morb Mortal Wkly Rep 2018; 67(22): 643-645.

49. Kelso JM, Greenhawt MJ, Li JT. Joint Task Force on Practice Parameters (JTFPP). Update on influenza vaccination of egg allergic patients. Ann Allergy Asthma Immunol 2013; 111(4): 301-302.

50. Greenhawt M, Turner PJ, Kelso JM. Administration of influenza vaccines to egg allergic recipients: a practice parameter update 2017. Ann Allergy Asthma Immunol 2018; 120(1): 49-52, doi: 10.1016/j.anai.2017.10.020.

51. Public Health Agency of Canada. National Advisory Commitee on Immunisation (NACI) Canadian Immunization Guide Chapter on influenza and statement on seasonal influenza vaccine for 2017-2018. Ottawa, Ontario; 2017.

52. AAP Committee on Infectious Diseases. Recommendations for prevention and control of influenza in children, 2017-2018. Pediatrics 2017; 140: e20172550.

53. Grohskopf LA, Sokolow LZ, Broder KR, et al. Prevention and control of seasonal influenza with vaccines: recommendations of the Advisory Committee on Immunization Practices - United States, 2017-18 Influenza Season. MMWR Recomm Rep 2017; 66: 1-20. 
54. Charakterystyka produktu leczniczego [cited 18.12.2019]. Available from URL: http://leki.urpl.gov.pl/files/40_VaxigripTetra.pdf (in polish).

55. Charakterystyka produktu leczniczego [cited 18.12.2019]. Available from URL: https://gdziepolek.blob.core.windows.net/product-documents/doc59317/influvac-tetra-przeciw-grypie-dokument.pdf (in Polish).

Tables: 8

Figures: 2

References: 55

Received: 29.01.2019

Reviewed: 20.02.2019

Accepted: 19.03 .2019

Address for correspondence:

Zbigniew Doniec, MD, PhD, Assoc. Prof.

Klinika Pneumonologii

Instytut Gruźlicy i Chorób Płuc OT w Rabce-Zdroju

ul. Prof. J. Rudnika 3B

34-700 Rabka Zdrój

Polska

Tel.: 18 267-60-60

E-mail: zdoniec@igrabka.edu.pl 